\title{
Globalization as a Constraint to Development in Africa: The Nigerian Experience
}

\author{
Taiwo Makinde ${ }^{1}$ \\ ${ }^{1}$ Department of Public Administration, Obafemi Awolowo University, Ile-Ife, Nigeria \\ Correspondence: Taiwo Makinde, Department of Public Administration, Obafemi Awolowo University, Ile-Ife, \\ Nigeria. Tel: 234-803-401-1114. E-mail: ayinkemakinde@yahoo.com
}

\author{
Received: August 28, 2013 Accepted: September 13, 2013 Online Published: October 11, 2013 \\ doi:10.5539/par.v2n2p191 URL: http://dx.doi.org/10.5539/par.v2n2p191
}

\begin{abstract}
Globalization, a process of international integration or international network through interaction in the areas of trade, culture, finance, investment, and technological interconnectedness has been described by scholars as a means of promoting growth, especially economic growth, in African countries. The claim of its being a means of promoting growth does not seem to manifest in many African countries, including Nigeria. The present paper intends to focus on financial liberalization (an aspect of globalization) in its discussion. Financial liberalization has to do with the collapse of national boundaries to money transfer by the multinational organizations, as well as transfer of technology, and the political economy of aids to African countries, among others. The discussion in this paper will concentrate on the ways that globalization (financial liberalization) has failed to contribute to development in many African countries, especially Nigeria. It is expected that the paper will shed light on why globalization has failed to bring the expected development to many African counties, Nigeria inclusive.
\end{abstract}

Keywords: globalization, development, constraint, financial liberalization, trade liberalization

\section{Introduction}

The world is shrinking day by day, not physically but through international interaction. With this, the world is becoming one big village. The world has become one big global village which has brought with it international integration resulting from the interchange of national and cultural resources. Both the developed and the developing nations now depend on each other for economic and cultural activities. This international interaction is what is referred to as globalization.

This paper looks at the effect of globalization on development in Nigeria. It focuses on two aspects of globalization (trade and financial) since the two go hand in hand. As the two have economic implications for developing countries, Nigeria inclusive, it is expected that the paper will be able to show how globalization has contributed to under-development in Nigeria, thus leading to governance crises.

\section{Conceptual Review of Globalization}

Some historians have claimed that globalization started in 1492 when Columbus stumbled on the Americas in search of spices, and in 1498 when Vasco da Gama made an end run around Africa snatching monopoly rents away from the Arab and Venetian spice traders (O'Rourke \& Williamson, 2000). These historians appear to be on the side of Smith (cited in O'Rourke \& Williamson, 2000) who believed that the events of 1492 and 1498 were the most important ones in recorded history regarding globalization. However, it has been argued that the two dates have no evidence supporting their economic impact on the global economy assigned to them by world historians, while there is abundant evidence supporting the view that the $19^{\text {th }}$ century contained a very big globalization bang, one of which is colonization.

The term globalization is derived from the word 'globalize, which refers to the emergence of an international network of social and economic systems. It has different meanings to different people. While the term can be defined as a process of international integration of economics and societies, it can also be defined as the loss of an important portion of the economic sovereignty (Majekodunmi \& Adejuwon, 2012). This definition appears curious because many people are of the opinion that globalization implies positive implication to every nation concerned. However, the definition as given by Majekodunmi \& Adejuwon, cited above, shows that globalization can bring positive, as well as negative results. For example, trade liberalization which relaxes rules 
and regulations governing trade among nations, most of the time, favours the developed countries while it sometimes has negative effects on developing countries like Nigeria.

Another scholar, Nkurayija (2011) sees globalization as a convergence of economic, political and cultural systems. Such convergence may not necessarily bring positive results, going by the claim made by Majekodunmi \& Adejuwon above. Nkurayija's definition shows that globalization is not restricted to economy, but also extends to politics and culture. Some borrowed political system and culture, in some cases, do not work for African countries as is the case with Nigeria. For instance, the Nigerian experience of alien political system is gulping a huge amount of money which would have been utilized for the development of the country. As for culture, some imported cultures have actually ruined the value system of the people, especially the youth.

In addition, globalization tends to displace tradition for modernization. Hence, new political institutions find it difficult to address the yearnings of new system. For instance, the Nigerian model of democratic enthronement of leaders encourages heredity, integrity and fame as against the adoption of money-gulping electoral system that is peculiar to western democracy. The Presidential system of government borrowed from the United States of America has proved to be very expensive to maintain. Perhaps, Nigeria is not practicing it the way it is practiced in the US from where it was borrowed. Apart from the political issue, many cultures have crept into Nigeria as a result of globalization. They include dancing, dressing, music, and language. In Nigeria, for example, musicians no longer pay attention to the lyrics of their songs. What the youth want to hear is noisy music even when it has no meaning. Also, the Nigerian language, especially Yoruba, is gradually being abandoned for English language. Some parents are no longer interested in speaking the native languages to their children. Everyone wants to speak English, even when it is wrongly spoken. It is a known fact that language plays a crucial role in development. When therefore, people abandon their local languages, it will have a negative effect on the development of such a country because loss of mother tongue amounts to loss of identity.

Another interesting definition is that given by Larsson (2001) which equates globalization with the process of world shrinkage, of distances getting shorter, and things moving closer. By implication, globalization increases the ease with which somebody on one side of the world can interact, to mutual benefit, with somebody on the other side of the world. Again, his definition emphasizes shrinkage in distance. Alamin Mazrui, 2001 (cited in Dotun Oni, et.al. 2008:20), defines globalization as "a process by which different regions of the world are pulled together through an expanding network of exchange of peoples, ideas and cultures as well as goods and services across vast distances". His definition is suggestive of shrinkage of distance as claimed by Larsson.

In their review of literature on globalization, KAI and HAMORI (2013) highlighted the neo-classical theory on the issue as a theory which believes in globalization as a means of boosting efficiency and promoting economic growth "through improved resource allocation and technology transfer". On the other hand, their review also revealed that some economists argue against the neo-classical scholars that liberalization reduces inequality. They claim that rather than reduce inequality, it actually worsens it in developing countries.

Merrian-Webster's Online has eulogized globalization as "the development of an increasingly integrated global economy marked by free trade, free flow of capital, and trapping of cheaper foreign labour market". Examining this definition, there is a clear indication that globalization brings in not only free trade but also free flow of capital. In a country like Nigeria, globalization has enabled the multinational companies such as the MTN and DSTV Communications to make so much profit from the country, but at the same time, carry their huge profits out of the country without much consideration for utilizing such profits to develop the country. More importantly, the two companies above (MTN and DSTV) have no shareholders in Nigeria.

From the examination of the various definitions, the paper will like to define globalization as the process of making the world one big village with access to the wealth and cultures of other countries, but with its challenges. While the benefits tilt more towards the developed countries, the challenges tilt more towards the developing nations. Since the focus of this paper is on financial liberalization and trade liberalization, the two concepts are examined below.

\subsection{Financial Liberalization}

Financial liberalization, sometimes called economic liberalization, means the collapse of national boundaries to money-transfer by multinational organizations as well as free flow of capital. By implication, the foreign partners are free to remit to their various countries any amount of money without any problem. Financial liberalization also connotes transfer of technology, and the political economy of aids to African countries, among others. It refers to reduction of any sort of regulations on the financial industry of a given country, i.e. lessening restrictions on various types of lending institutions and instruments. Such institutions include banks, a country's treasury (or whoever issues bonds) money market funds as well as investment bank. Ask.com (2013) explains 
further that financial liberalization is the greater access to international capital, facilitated in part through an expanded role for foreign banks and non-bank financial institutions. It goes further to state that it improves the allocation of resources in the economy, as capital is allocated to sectors for greater profitability. In its broadest context, financial liberalization is said to represent the situation where financial institutions make more credit available to consumers while it leads to unified financial markets.

Wikipedia (2013) refers to it more as economic liberalization which is associated with classical liberalism. Thus, liberalization, in short, refers to "the removal of controls" to encourage economic development. Liberalization include partial or full privatization of government institutions and assets, greater labour market, flexibility, lower tax rates for business, as well as less restriction on both domestic and foreign capital open markets, among others.

In the case of developing countries like Nigeria, economic/financial liberalization refers to further "opening up" of their respective economies to foreign capital and investments (Wikipedia, 2013). While some countries like Brazil, China and India have benefitted immensely as a result of liberalization, some have experienced insignificant growth in the economy.

Some countries are found to be operating in the opposite direction of economic /financial liberalization. The North Korea's economy is a good example. It runs a self-sufficient economic system that is closed to foreign trade and investment. However, according to Wikipedia (2013) North Korea is not completely separated from the global economy as it receives aid from other countries in exchange for peace and restriction in their nuclear programme.

Financial liberalization has led to privatization of government businesses in Nigeria but, that notwithstanding, due to the non-openness of trade transactions, most of the privatized companies have not succeeded in improving the economic growth of Nigeria. It has been debated that some government organizations cannot be privatized because of their sensitive nature. For example, the electricity sector ought to be managed by government as it will amount to leaving the security of the nation in the hands of foreigners, thereby opening the country's electricity supply to sabotage. As has been discussed earlier, part of financial liberalization is trade liberalization which will be discussed below.

\subsection{Trade Liberalization}

With trade liberalization, goods are brought in without restriction into the country under the guise of free trade and, at a cheaper cost to the people, thereby making goods made in the host country to be abandoned by her own people even when such goods are superior in quality to the imported ones. Furthermore, trade liberalization also has the tendency to weaken the ability of infant industries to compete and become potentially useful for the quest of economic development. This is explainable by the fact that trade liberalization compels nations to open their borders to cheap services and goods which will make it difficult for domestic industries to actualize and realize their interests.

Trade liberalization enables goods from other countries to be brought into another country without any restriction. Such goods are usually cheaper and more affordable to the people resulting in the people of the country preferring the imported goods to those made in their own country. For example, made-in-Nigeria goods are abandoned by Nigerians as a result of such international practices because of the price differentials, even when such goods are superior in quality to the imported ones. When goods made in any country are rejected by its own people as a result of the influx of foreign goods brought in under trade liberalization, indigenous companies are forced to fold up as a result of stiff competition. A good example is the garment industries in Nigeria which produce print materials (Ankara) and guinea brocade. Most of these companies have folded up while some have reduced their work force. This automatically leads to reduction in employment opportunities to the indigenes. The resultant effects are unemployment, hunger, and sickness. Unemployment has led to an increase in the crime rate in Nigeria as many people, young and old, take to crime such as kidnapping, robbery, assassination and ritual killings, among others, in order to make money.

The conventional view that trade liberalization is necessary and has automatic and generally positive effect for development is being challenged empirically and analytically. While some scholars consider trade liberalization as being positive for, and essential to, growth and development, others complain that it has produced negative results for their economies. Only a few countries have enjoyed moderate or high growth in the past three decades while a great number have actually suffered declines in living standards. The problem may not be unconnected to the fact that the playing ground is not level. The odds are heavily tilted in favour of the industrialized world, given that the current participation of Africa in world trade is only 2 percent, (Dotun Oni, et. al. 2008). In a study carried out by Hisako KAI and Shigeyuki HAMORI (2013) on globalization and its effect on Sub-Saharan 
Africa (on-line), it was concluded that as a result of globalization in Sub-Saharan Africa, "the rich have become richer and the poor have become poorer" (p.1). It appears that developed nations try to counter attempts being made by developing nations to reduce the influence of developed nations. There is a Yoruba saying which goes thus: Olorun ma je ki eni to go gbon, ki eniti o gbon le ma ri nkan je (God should not allow the foolish to become become wise so that the wise will continue to exploit the foolish). Nigeria is among the countries that have been adversely affected by trade liberalization as it has worsened inequality between her and the developed countries with which she engages in trading. The citizens are getting poorer while government finds it difficult to provide adequate essential social amenities to the citizenry. Such amenities include potable water supply, electricity, good roads, good health facilities and, most especially, security. However, Massimiliano, et al. (2008) has argued that the risks involved in trade liberalization are outweighed by the benefits, especially with careful regulation by the government.

Since the paper's attention is focused on the effect of globalization on development in African countries, it is important that the concept of development be looked into in order to examine how the two concepts globalization and development - relate in the study.

\section{Conceptual Review of Development}

The definition of development depends on the perspective from which it is being considered. For this paper, development shall be considered from the perspective of process of change, positive change, which is crucial to any developing country, such as Nigeria. The indices of development are human growth, income, and access to social amenities and which can be summed up as human development. Human development, according to United Nations Document (1996), emphasizes the measurement of human development by life expectancy, adult literacy, access to all three levels of education, as well as people's average income, which is a necessary condition of their freedom of choice". Human development, as a matter of fact, incorporates all aspects of a person's well-being ranging from health status to his economic and political freedom.

Development as a concept is complex because it can be defined from different perspectives. According to Oladoyin (2010:74), the neo-liberals argue that "an independent price-mechanism may occasion a spontaneous process of development, while the structuralists see development as encompassing changes in social and economic structures. According to him, the interventionists, on their part, argue that unfettered market economy is prone to bringing poverty, unemployment and economic oppression of man to man by reasoning that the market is just too germane to be left unregulated. Can one then say that the interventionists are not in support of trade deregulation or liberalization? The answer will be in the negative. What they seem to highlight is the fact that trade and financial liberalization should be done with adequate regulations by the government in order for it to be effective. The problem of poverty and other vices brought about by trade liberalization might have been avoided if there are some restrictions imposed. Chambers (2012) defines development as "good change". The definition presupposes that there is "bad change". Therefore, in line with Chambers' definition, development means progress. However, some scholars have argued that development is not synonymous with progress. In his own view, Thomas (2000) claims that progress implies continual development reaching higher and higher levels perhaps without limit, whereas development, as an analogy from the development of living organisms, implies moving towards the fulfillment of a potential. Agagu (citing Thomas, 2000:5) defines development as "escape from underdevelopment while Mabogunje (1995) views it from the perspective of wealth creation. Igbuzor, 2005:22 (cited in Oladoyn, 2010) on his part, views development from three perspectives, first as a "vision, description or measure of the state of being of a desirable society", second, as a historical change "in which societies are transformed over a long period of time; while the third is as "consisting of deliberate efforts aimed at improvements on the part of various agencies including governments and all kinds of organizations and social movements". Citing Igbuzor further, Oladoyin (2010:74) claims that different people have different visions of what is desirable based on their ideological inclination. He highlighted three different views of vision:

The first one is the vision of a modern industrial society, which is elaborated by modernization theories. The second is a society where every individual potential can be realized in conditions characterized by the capacity to obtain physical necessities (particularly food), employment, equality, participation in government, political and economic independence, adequate education, women equality, sustainable development and peace. The third vision is the one that sees development as reducing poverty, improving health, mitigating environmental degradation, etc. (p.74).

The second description of 'vision perspective' highlighted by Oladoyin (2010) shall be the focus from which the paper will look at globalization and development in Nigeria. This is where development is seen from the perspective of a society where there is food, employment, equality, adequate education, as well as sustainable 
development and peace, among others. The definition agrees with that of Mabogunje earlier discussed. Development in Africa can be linked to the dependency theory which allows development with external links with the developed parts of the globe. Dependency thinking starts from the notion that resources flow from the 'periphery' of the poor and underdeveloped states to a core of wealthy countries, which leads to accumulation of wealth in rich states at the expense of the poor states. The poor countries are thereby made to look up to the developed nations almost all the time.

How has globalization contributed to under-development of African countries in general and Nigeria in particular. This is the next line of focus.

\section{Globalization as a Constraint to Development: General Overview}

How far has globalization affected the development of Nigeria going by the second view of vision which talks about every individual realizing his potentials under a conducive environment where there is no hunger, where there is employment, equality, participation in government; where there is sustainable development and peace, and where there is political and economic independence.

It is important to observe that most African countries, Nigeria inclusive, have been under some form of global influence through colonization. Many of them were under the colonial rule for many years before their independence. Many African countries were partitioned among European powers. Some went to the French, some to the Portuguese and some to the British. Nigeria is among those ceded to the British rule, and it became independent in 1960. Dotun Oni, et.al.(2008) claimed that:

The phenomenon of globalization came to Nigeria for the first time, not just in the last century, as it is generally thought, but when the Portuguese and the British landed on our shores before the end of the $19^{\text {th }}$ century to establish new trade links and to spread Christianity. (p.21).

According to Agagu, (2011:11), 'the scramble for Africa and its ultimate partition among the various European powers provides a clue to understanding the nature and motive of the states that emerged in Africa'. It is evident that the interest of the colonial masters was a selfish one. They came to exploit the wealth of the various nations, as well as dominate its people. This basically underlined the operations of colonies of exploitation which operated in Nigeria. Resources were tapped and siphoned to Europe to develop their societies to the detriment of African states. The nature and the motive of the states that emerged were not meant to favour the colonized nations but rather to boost the economy of the colonialists. Gavin and Betley, 1973, also see the partition of Africa by European powers as an action which situates African history within the canvas of European politics.

Ihonvbere (1989:15-27) observed that the contact with Europe only distorted, disarticulated and underdeveloped Africa, while Rodney (1972:34) had this to say:

African economies are integrated into the very structure of the developed capitalist economy; and they are integrated in a manner that is unfavorable to Africa and ensures that Africa is dependent on the big capitalist countries.

The idea of dependence was further buttressed by Onimode (2000:72-73) when he claimed that -

The colonizing predators through forcible incorporation of colonial Africa into the international capitalist economy denied it, and its people, a free role to play in their socio-economic responsibility in individual, social, national and world affairs.

By implication, African states were conditioned to produce raw materials that were used to develop European states. It symbolizes a moving train under the control of developed states and African countries are forcibly compelled to join by the wicked machines like World Trade Organization (WTO), International Monetary Fund (IMF) and the World Bank. All the above have made many African countries to remain dependent on their colonial masters. Nigeria is not an exception.

From the above discussion, it is evident that there has been a kind of globalization although not in the way that it is presently understood. The globalization, as at that time, was of master/servant relationship which was unfavourable to Africa in general and to Nigeria in particular. The present globalization, though not a master/servant relationship type, has its own way of turning the exercise against the African countries that buy into it. The Nigerian situation shall be discussed under two sub-headings, namely, socio-economic development and political development.

\subsection{Globalization as a Constraint to Socio-Economic Development}

Despite the expectation that trade and financial liberalization would improve the economy of Nigeria and, by extension, its people, the contrary has been the situation as incidence of poverty appears to be on the high side in 
the country. The World Bank Report of 1999 also revealed that nearly $70 \%$ of Nigeria's populations of about 120 million live below the poverty line. The World Bank Report (1999) on Nigeria referred to above is corroborated by the data from the Federal Office of Statistics (1999) which states that the index of poverty has been on the increase since independence in 1960, with an astronomic growth from $15 \%$ in 1960 , to $28 \%$ in 1980 and $66 \%$ in 1996. All these anomalies are in spite of the trade liberalization on ground. In the National Economic Empowerment and Development Strategy's (NEEDS) document (2004) published by the UNDP, Nigeria is reported to have a Gross Domestic Product (GDP) of about $\$ 45$ billion in 2001, and a per capita income of about $\$ 300$ making her one of the poorest countries in the world. The 2005 Report of the United Nations Development Programme (UNDP) Human Development Index (HDI) showed Nigeria as occupying the $158^{\text {th }}$ position on the Human Development Index. Norway came first, while Niger came last at $177^{\text {th }}$ position (http://hdr.undp.org). According to the Poverty Document on Nigeria (2005), the population of Nigerians in poverty has increased from 17.7 million in 1980 to 68.7 million in 2004. This is an increase of $51 \mathrm{~m}$ in 24 years! Also, by the Report of the National Bureau of Statistics' Poverty Profile of 2006, 52\% of the population, i.e., over 70 million people which is more than the figure of 2004 quoted above, live on less than one dollar a day in Nigeria (http://www.dfid.gov.uk/pubs/files/nigeria-factsheet.pdf). The recent Report from the National Bureau of Statistics (2010), shows that 112.5 million Nigerians live in poverty. This is out of a population of 163 million, giving us $69 \%$ of the population as living in poverty.

Under the socio-economic issues being discussed are problems of unemployment, especially that arising from manufacturing companies closing down their businesses as a result of their inability to compete with foreign imported goods. The increase in unemployment rate has resulted in increase in crime rate in Nigeria such as kidnapping, armed robbery, assassination, and ritual killings for money making, among others. The rate of kidnapping has reached an alarming stage and has therefore, constituted a security threat to the nation. Some people (Nigerians and foreigners) have actually relocated from the country because of the fear of being kidnapped. Commenting on the problem of kidnapping in Nigeria, The Nation ( September 13, 2013, p.30) attempts to analyze why kidnapping has become a thriving business in Nigeria

From the testimonies of many kidnap victims, it could be said that the motives behind kidnapping include poverty, high level of unemployment, get-rich-quick syndrome, porous and inadequate security, intelligence gathering, greed and erosion of value system (p. 30).

Three things came out clearly as consequences of globalization, namely, high level of unemployment, poverty and erosion of value-system. In our earlier discussion in this paper, globalization has been shown to have brought in alien cultures which have polluted the value system of the people, especially the youth who no longer value those things such as hard work, honesty, integrity, all of which used to be part of the Nigerian peoples' culture before globalization.

In addition to poverty, financial liberalization has brought with it global corruption which has impeded development in Nigeria. Global corruption is that corruption which goes beyond the local, state and national levels. It goes beyond the shores of any nation. At this level of corruption, the economic system of the affected nations is badly affected because, according to the write-up in global issue (2012), "the international economic system that has shaped the current form of globalization... has also created conditions whereby corruption can flourish and exacerbate the conditions of people around the world who already have little say about their own destiny". This statement is connected to the form of corruption perpetuated at the global level by the developed countries, especially against the developing nations. It is a form of corruption that has brought governance crises to the affected countries some of which find it difficult to provide essential amenities to the people due to lack of fund arising from embezzlement of resources. In addition to global corruption, the advice from International Organizations such as the World Trade Organization (WTO), International Monetary Fund (IMF) and the World Bank has led to poverty in Nigeria.

A good example is the Structural Adjustments Programme (SAP) suggested by the International Monetary Fund (IMF) and implemented by General Babangida. SAP prescribed devaluation of the Naira while it gave the impression that such devaluation would attract foreign investments to Nigeria. Although foreign investors came in but the game was not played on a level ground because the national currency has been badly devalued to such an extent that an investor needs only a few thousand dollars and he becomes a millionaire/billionaire in Nigeria. The structural adjustment programme actually ruined the Nigerian currency and its economy.

Another problem is the huge debts arising from foreign loans which affect the availability of funds to carry out important projects that would enhance development in the country. Unfortunately, these loans are readily made 
available to the developing countries through financial liberalization. Such loans are capable of turning any country to a permanent debtor country.

The political economy of aids to African countries cannot be ignored. It has been observed that most aids given to African countries by the developed countries such as America and Britain do not bring the desired development. According to Browne, 2007:6, "There is a growing body of evidence that traditional forms of development aid do not make a major difference". He cited the under-listed as some of the problems affecting the effectiveness of the aids:

(i) Most aid is administered by many large and expensive public bureaucracies, each with procedures of their own.

(ii) Supply is excessive, duplicative and pre-financed.

(iii) Recipient countries are chosen according to the instincts of northern politicians and donor self interests.

(iv) The content and terms of aids strongly influenced by theneeds and interests of the suppliers rather than the recipient,

The above are in addition to stringent conditions attached to these aids which are capable of frustrating the recipient countries. This is not to conclusively aver that foreign aids are detrimental to development. However, it must be emphasized that donors will always expect "rewards" from their investments. Some of what they get in return might pose a threat to the survival and developmental quest of recipient states. Hence, a balanced trading pattern and internally generated development should be encouraged.

On social service delivery, the highlighted problems in Nigeria arising from globalization have contributed to non-performance on the part of government. A 53-year old nation (Nigeria became independent in 1960) that cannot supply its people with regular electricity cannot be regarded as being developed. Many things that can contribute to development and economic growth are tied to electricity or what is referred to as power supply. Manufacturers rely on it to produce their goods and, by implication, develop their businesses. It is no exaggeration to say that many things that can contribute to development are tied to effective electricity supply. Such things include production, technology, and health provision, among others. Without adequate electricity supply, economic growth through production cannot thrive as manufacturers may have to source for their own power supply as is being done in Nigeria. Such self provision of electricity automatically increases cost of production and makes trade to be highly competitive especially with goods produced in other countries. Such inadequacy has led to some companies relocating to a more conducive environment outside the country. Such is what is happening in Nigeria where some manufacturing companies such as the Dunlop Tire Company and Coca-Cola Company have actually relocated to Ghana, a neighbouring country. What they have left in Nigeria is a skeletal structure.

\subsection{Globalization as a Constraint to Political Development}

The colonization of Nigeria by the British is considered to be a form of globalization. Colonization actually gave Lord Luggard the opportunity to force the union of the Northern and Southern Protectorates which became Nigeria in 1914. The 1914 amalgamation of the two Protectorates (Northern and Southern Protectorates) by Lord Luggard has negatively affected the political terrain of Nigeria. For Nigeria, the amalgamation of the Northern and Southern Protectorates failed to put into consideration the cultural and religious diversity of the two sections, and this action has resulted in conflict of interest among the two groups ever since. It was even suggested by Agagu (2011) that the amalgamation was "essentially based on the economic motive" of the colonial masters. The failure to consider the socio-cultural incongruence of the two protectorates before amalgamation had great impact on the nature of state which emerged from the exercise. The state was unstable and undeveloped with artificial boundaries that are prone to wars/conflict, multiplicity of societies that parade colonial intrusion, burden of economic weakness, external dependence, creation of western educated elites, fragility of state institutions, absence of shared political culture and the collective memory of humiliating aspect of colonialism (Chazan, et. al. 1999).

Since the Nigerian independence in 1960, the country has witnessed political instability arising from problems created by the 1914 amalgamation. Even as at 2013, politics is still being played along the ethnic divide as is being experienced through the rejection of President Goodluck Jonathan contesting for the Presidency in 2015. His rejection is based on the fact that he is not from the northern part of Nigeria. Whoever comes in as the president is likely going to think of himself first as someone from the South-west, South-east, South-south, North-west, North-east and North-central. With this at the back of his/her mind, policies that are formulated are 
also likely going to tilt in favour of the people from the home state of the president rather than in favour of the generality of the people.

It cannot be faulted that where there is political instability there cannot be development because most of the time, the people at the helms of affairs will be battling with crises rather than facing the work of governance. The Boko Haram insurgency is a good example of ethnically and politically motivated crisis. The insurgency has threatened the peace and security of the country. These terrorists have killed many innocent people including school children, as well as destroyed properties worth millions of Naira. These terrorists find followers among the teeming unemployed and uneducated youth especially from the northern part of the country. Although they make the crisis look like religious, many have seen it more as being a political crisis precipitated to ensure that President Jonathan does not contest in the 2015 general elections and also to ensure that a northerner becomes the president of Nigeria, come 2015. With the prevailing insecurity in Nigeria, there is no doubt that political development cannot be rapid.

\section{Conclusion}

This paper has found that globalization, especially financial and trade liberalizations were found to constitute major constraints to the socio-economic, as well as political development of Nigeria. The colonization of Nigeria was considered as a form of globalization which has contributed negatively to the political development of Nigeria. The interventions of international organizations such as the IMF and the World Bank have negatively contributed to the economic development of the nation. The political economy of aid to African countries was also a major factor to economic under-development because it has brought about dependency syndrome on some of these countries, Nigeria inclusive, as they depend on foreign aids for many of their programmes such as health, technology and education.

However, globalization cannot be totally condemned because it has enabled peoples from different cultures and backgrounds to learn from one another. It has also made technology transfer possible. Even though it appears that its negative effects outweigh the positive ones as highlighted in this paper, I would like to align with Dotun Oni, et al. (2008) when he said that:

Globalization is not such a bad thing. It has contributed, it is true, to devastation and the pangs of poverty that are being experienced in this country and Africa generally. But I think it is also a wake-up call to many things that ought not to happen to us and to many things that we ought to think about and to do in order to improve the lot of our people. (p.21)

African countries in general should find a way of making use of the good attributes of globalization and, at the same time, work towards developing their people without depending on foreign aids and without agreeing to every suggestion made by the world authorities such as the WTO, IMF and the World Bank. The level of dependency of the developing countries on the developed states should be drastically reduced. This can only be achieved when African nations generally, and Nigeria in particular, decide to hold their destinies in their own hands.

\section{References}

Agagu, A. A. (2011). The Nigerian State and Development: A Theoretical and Empirical Exploration. In A. A. Agagu, \& R. F. Ola (Eds.), Development Agenda of the Nigerian State (pp. 3-30). Akure: Lord Keynes Publishing Company.

ASK.com. (2013). What Is Financial Liberalization? Retrieved 2009/2013, from http://www.ask.com.question/what-is-financial-liberalization

Browne, S. (2007, October). Target the MDGs Not Aid Amounts. In Poverty in Focus (pp. 6-7). Brazil: Publication of the International Poverty Centre.

Chambers, R. (2012). Participation for Development: A Good Time to Be Alive. Abbreviated keynote to the ACFID Conference in Canberra on November 28, 2012. Retrieved September 20, 2013, from http://archanth.anu.edu.au/sites/defaults/files/Chambers Keynote.pdf

Chazan, N., Peter, L., Robert, M., Donald, R., \& Stedman, S. J. (1999). Politics in Contemporary Africa. Colorado: Lynne Reiner.

de la Nkurayija, J. C. (2011). The Impact of Globalization on Africa's Development: Rwandan Tourism as Key to Mobilize Revenue.

Federal Government of Nigeria (FGN). (2005). NEEDS Documents (Draft). 
Federal Office of Statistics. (1999). Poverty Profile on Nigeria.

Garvin, R., \& Betley, J. (1973). The Scramble for Africa. Ibadan: Ibadan University Press.

Global Issues. Retrieved January 20, 2012, from http://www.globalissues.org

Globalization. (2012). Online Etymology Dictionary. Retrieved July 7, 2012, from http://www.etymonline.com/ex.php?term=globalization

Human Development Report (HDR). (2005). Retrieved from http://hdr.undporg

Igbuzor, O. (2005). Perspectives on Democracy and Development. Lagos: Joe - Tolalu \& Associates.

Ihonvbere, J. (Ed.). (1989). The Political Economy of Crisis and Underdevelopment in Africa. Selected Works of Claude Ake. Lagos: JAD Publishers.

Kai, H., \& Hamori, S. (2013). Globalization, financial Depth, and Inequality in Sub-Saharan Africa.

Larsson, T. (2001). The Race to the Top: The Real Story of Globalization. Washington D.C.: Cato Institute.

Mabogunje, A. (1995). A Concept of Development. Working Paper. Ibadan: Development Policy Centre.

Majekodunmi, A., \& Adejuwon, K. (2012). Globalization and African Political Economy: The Nigerian Experience. International Journal of Academic Research in Business and Social Sciences, 2(8), 189-205.

Makinde, T. (2008). An Appraisal of the National Poverty Eradication Programme (NAPEP) in Selected States of Southwestern Nigeria. (Ph.D Thesis). Department of Public Administration, Obafemi Awolowo University, Ile-Ife, Nigeria.

Massimiliano, C., Ellis, K., \& Willem te Velde, D. (2008). The Contribution of Services to Development: The role of regulation and trade liberalization. London: Overseas Development Institute

Mazrui, A. (2001). Unpublished Public Lecture given at the Center for African Studies, Livingston Campus, Rutgers University, New Jersey.

Merrian-Websters Online. (2013). Definition of Globalisation. Retrieved from http://www.merriam-webster.com/dictionary/globalisation

National Bureau of Statistics. (2006). Poverty Profile on Nigeria. Retrieved September 20, 2013, from http://www.dfid.gov.uk.pubs/files/nigeria-factseet.pdf

National Bureau of Statistics. (2010). Nigeria Poverty Profile Report, 2010.

O'Rourke, Kevin, H., \& Williamson, J. G. (2000). When did Globalization Begin? Working Paper 7632. National Bureau of Economic Research, Cambridege, MA. Retrieved from http://www.nber.org/papers/w7632

Oladoyin, A. M. (2010). Donor Agencies, Governance and Development in Nigeria. In F. Omotoso, A. A. Agagu, \& O. Abegunde (Eds.), Governance, Politics and Policies in Nigeria: An Essay in Honour of Prof. Dipo Kolawole (pp. 65-84). Porto Novo: Editions SONOU d'Afrique (ESAF).

Oni, D., Gupta, S., Omoniyi, T., Adegbija, E., \& Awonusi, S. (2008). Nigeria and Globalization: Discourses on Identity Politics and Social Conflict. Lagos: Centre for Black and African Arts and Civilization (CBAAC).

Onimode, B. (2000). Africa in the World of the $21^{\text {st }}$ Century. Ibadan: Ibadan University Press.

Rodney, W. (1972). How Europe Underdeveloped Africa. Enugu: Ikenga Publishers.

Smith, A. (2000). Cited in O'Rourke, et al. above.

Thomas, A. (2000). Meanings and Views of Development. In T. Allen, \& A. Thomas (Eds), Poverty and Development into the $21^{\text {st }}$ Century. Milton Keynes: Oxford University Press.

United Nations (UN). (1996). Human Development Report.

United Nations Development Programe (UNDP). (2005). Internal Cooperation at a Crossroads: Aid, trade and Security in an unequal world. Retrieved September 20, 2013, from http://hdr.undp.org/en/media/HDR05.complete.pdf

United Nations Development Programme (UNDP). (2004). National Economic Empowerment and Development Strategy (NEEDS), Abuja. Retrieved September 20, 2013, from http://www.ng.undp.org/documents/NEEDS/NEEDS.pdf 
Wikipedia, the free encyclopedia. (2013). Development Theory. Retrieved September 20, 2013, from http://www.en.wikipedia.org/wiki/Development_theory

Wikipedia, the free encyclopedia. (2013). Economic Liberalization. Retrieved September 18, 2013, from http://www.en.wikipedia.org/wiki/Economic_liberaliazation

World Bank. (1999). Voice of the Poor: Reports. Retrieved September 20, 2013, from http://web.worldbank.org/WBSITE/EXTENAL/TOPICS/EXTPOVERTY/O

\section{Copyrights}

Copyright for this article is retained by the author(s), with first publication rights granted to the journal.

This is an open-access article distributed under the terms and conditions of the Creative Commons Attribution license (http://creativecommons.org/licenses/by/3.0/). 